\title{
É PRECISO MAIS QUE BARRO PARA CONSTRUIR UM HOMEM: A IDENTIDADE DO PERSONAGEM MASCULINO NO CONTO “A MENSAGEM”, DE CLARICE LISPECTOR
}

\section{IT TAKES MORE THAN CLAY TO BUILD A MAN: THE IDENTITY OF THE MALE CHARACTER IN THE SHORT STORY “THE MESSAGE”, BY CLARICE LISPECTOR}

\section{Leandro Lopes Soares* \\ UERN}

\section{Maria Eliane Souza da Silva** UERN}

\section{Maria Edileuza da Costa*** UERN}

\begin{abstract}
Resumo: Para poder escrever, a mulher teve de batalhar para conquistar o direito de escrita e representar a si mesma de seu próprio ponto de vista. Conquistado esse direito, a mulher escritora passou a retratar também homens como personagens de seus romances, novelas, contos, crônicas e poemas; entre estas que se aventuraram nesse desafio, destacamos Clarice Lispector. Com uma vasta bibliografia acerca de sua obra, principalmente sobre a personagem feminina, propomos um estudo voltado para uma vertente pouco discutida da literatura lispectoriana: o personagem masculino. Nesse ensejo, destacamos, como objetivo maior, analisar o personagem masculino do conto “A mensagem”, de A legião estrangeira (1999) para entender como sua identidade é construída transpassada por condutas exigidas ao homem na sua juventude. À luz dos estudiosos da masculinidade, como Nolasco (2001), Oliveira (2004), Bourdieu (2016), entre outros, e da identidade (BAUMAN, 2005; HALL, 2015), nossa leitura aponta para uma representação masculina inscrita numa realidade ambígua, que, por vezes, ressalta traços hegemônicos de sua masculinidade, e, em outras, afasta-se, trazendo a lume a fragilidade humana, que independe do gênero.
\end{abstract}

Palavras-chave: Personagem masculino. Identidade. Gênero. Clarice Lispector.

\footnotetext{
* Mestre em Letras pela Universidade do Estado do Rio Grande do Norte (UERN). ORCID: https://orcid.org/0000-0003-33444532.E-mail: <leandrolls231@gmail.com>.

** Doutora em Literatura Comparada pela Universidade do Estado do Rio Grande do Norte (UERN). Pós-doutoranda - bolsista do Programa Nacional de Pós-Doutorado da Coordenação de Aperfeiçoamento de Pessoal de Nível Superior (PNPD/CAPES), Programa de Pós-Graduação em Letras da Universidade do Estado do Rio Grande do Norte (PPGL/UERN). ORCID: https://orcid. org/0000-0003-1571-7648. E-mail: <mariaeliane28@hotmail.com>.

*** Doutora em Letras pela Universidade do Estado do Rio Grande do Norte (UERN). Professora permanente do Programa de Pós-Graduação em Letras da Universidade do Estado do Rio Grande do Norte (PPGL/UERN). ORCID: https://orcid.org/00000001-5669-0109.E-mail: <edileuzacostauern@gmail.com>.
} 


\begin{abstract}
In order to write, women had to struggle to conquer the right to write and to represent themselves from their own point of view. By conquering this right, the woman writer began to also portray men as characters of their novels, chronicles, short stories and poems; among those who ventured into this challenge, we highlight Clarice Lispector. Counting with a large bibliography about her work, especially on the female character, we propose a study focused on a little discussed side of Lispector's literature: the male character. In this context, we highlight, as the main objective to analyze the male character of the tale "A mensagem", from A legião estrangeira (1999), to understand how his identity is built through the conducts required to man in his youth. In the light of scholars of masculinity, such as Nolasco (2001), Oliveira (2004), Bourdieu (2016), among others, and of identity (BAUMAN, 2005; HALL, 2015), our reading points to a masculine representation inscribed in an ambiguous reality, which sometimes emphasizes hegemonic traces of its masculinity, and in others, it is turned away, bringing to light the human frailty, which is independent of gender.
\end{abstract}

Keywords: Male character. Identity. Gender. Clarice Lispector.

\title{
PRIMEIRAS PALAVRAS
}

Os homens deviam ser o que parecem ou, pelo menos, não parecerem o que não são.

(William Shakespeare)

As discussões empreendidas neste estudo fazem parte de um projeto maior de pesquisa voltado para a análise do personagem masculino na obra de Clarice Lispector com foco nas produções em que eles são protagonistas. Outras narrativas lispectorianas também são investigadas no intuito de entender melhor as múltiplas faces do homem e sua relação com os demais elementos e seres que o cerca, entre eles a personagem feminina. Assim sendo, este texto constitui-se como um recorte e apresenta as primeiras problematizações acerca desse tipo específico de personagem nos contos. Além do conto “A mensagem”, outros dois textos (“O corpo” e “O jantar”) estão nesse mesmo encaminhamento, mas voltados para outras perspectivas analíticas a serem divulgadas em outras oportunidades. Por enquanto, decifremos o enigma proposto pela esfinge Clarice Lispector nas entrelinhas do escrito supradito, presente no livro A legião estrangeira (LISPECTOR, 1999).

Ao longo do tempo, a literatura propiciou a representação do ser humano em diferentes períodos históricos e diversos contextos sociais. Através da criatividade do autor, o sujeito masculino e o feminino foram abordados pela arte literária com enfáticas distinções entre os sexos, reforçando os estereótipos de homem e de mulher. O primeiro como um ser forte, viril, dotado de capacidades físicas e intelectuais, com livre acesso aos espaços públicos; e a segunda como um ser frágil, educada para o casamento, o cuidado com os filhos, subserviência ao marido, excluída dos espaços externos, restando-lhe apenas o triste aconchego de, em muitos casos, uma prisão sem grades conhecida como lar. Muitas dessas formas de representação têm origem nos personagens presentes nas narrativas bíblicas, bem como na mitologia grega, pois estes funcionam como modelo de socialização dos corpos, encaixando homens e mulheres em suas respectivas categorias. 
Desde a criação do primeiro homem, um estereótipo de masculinidade instaurou-se no mundo, perpetuando-se desde a antiguidade até os dias atuais. Do mesmo modo, um arquétipo de feminilidade marcado, principalmente por sua criação da costela de Adão, pela desobediência à ordem divina e indução do homem ao pecado original pelo ato simbólico de ter comido a maçã, é repassado. Adão e Eva, dois personagens bíblicos, os responsáveis pelo povoamento do mundo, serviram também de modelos para a perpetuação de um pensamento que perdura até a sociedade pós-moderna: o da superioridade masculina em relação à feminina ou a submissão da mulher à figura patriarcal.

Do mesmo modo, quando direcionamos um olhar mais atento aos personagens da mitologia grega, percebemos que a superioridade masculina em relação à figura feminina também é marcante. Ao tomarmos como exemplo um episódio de amor obsessivo em que é narrado o desejo irrefreável de um deus (Apolo) por uma ninfa (Dafne), vemos um comportamento não mais aceito na atual sociedade. Tendo como causa uma flechada dada por Eros, filho de Afrodite, uma das flechas atingiu Apolo deixando-o louco de amor pela ninfa, e a outra feriu a donzela, tornando-a avessa a esse sentimento. Esse relacionamento insistente da parte de Apolo não difere de muitos existentes nos dias atuais. A mulher não queria uma vida de casada, enquanto o homem queria isso a qualquer custo. Para ele, quase nada mudaria em sua rotina, mas, no caso dela, as transformações seriam drásticas.

Era como um cão perseguindo uma lebre, com a boca aberta, pronto para apanhá-la, enquanto o débil animal avança, escapando no último momento. Assim voavam o deus e a virgem: ela com as asas do medo; ele com as do amor. O perseguidor é mais rápido, porém, e adianta-se na carreira: sua respiração ofegante, já atinge os cabelos da ninfa. (BULFINCH, 2017, p. 31).

Tal comportamento do ser masculino foi por muito tempo considerado normal, pois o homem tinha direito sobre a mulher em muitas culturas, podendo assediá-la e sair impune, visto que, na maioria dos casos, ela se calava diante dessas atrocidades. É perceptível, no mito grego, a insatisfação de Dafne com a insistência de Apolo, que mesmo estando os dois sob efeito da flecha de Eros, propiciam uma reflexão social das relações amorosas, muitas vezes abusivas, tóxicas, mais uma vez com uma superioridade masculina em detrimento da feminina. A solução encontrada para escapar desse infortúnio foi ser transformada em árvore, abandonando sua existência física, sua liberdade, sua vontade de caçar, para viver em uma nova forma, estática e silenciada por sua condição social enquanto ser feminino.

Diante desses pressupostos e com base nas distinções entre o sexo masculino e feminino, bem como nos sistemas responsáveis pela socialização dos corpos, a saber, principalmente o patriarcado, realizamos, neste estudo, uma discussão acerca do homem protagonista dos contos de Clarice Lispector, mais especificamente do jovem personagem central da narrativa "A mensagem”, de A legião estrangeira. Nossa análise se volta para a construção de sua identidade, inicialmente por uma identificação seguida de um distanciamento da figura feminina, impulsionada, principalmente, pela descoberta da diferença. 


\section{UMA IDENTIDADE MASCULINA EM CONSTRUÇÃO: UMA LEITURA DO CONTO “A MENSAGEM”}

Ele-ela já estava presente no alto da montanha, e ela estava personalizada no ele e o ele estava personalizado no ela.

(Clarice Lispector)

Com características do Bildungsroman (romance de formação), pois o personagem desse tipo de narrativa passa por um processo de formação até alcançar um ponto específico para sua constituição como sujeito (MASS, 2000), o conto “A mensagem”, do livro A legião estrangeira (LISPECTOR, 1999), trata da descoberta das diferenças existentes entre os gêneros masculino e feminino. Os protagonistas da história são dois adolescentes angustiados por não se encaixarem na sociedade em que vivem, encontrando na amizade uma forma de amenizar essa angústia. Os dois percebem-se diferentes um do outro, revelando, assim, as dissimilitudes existentes entre homens e mulheres, quando se deparam com uma casa antiga e abandonada.

Manifestada inicialmente no rapaz, essa angústia é o primeiro dos sentimentos experimentados pelo garoto, pois, além dele, o jovem se vê diante de muitos outros, reprimidos à medida que são manifestados. Esse comportamento é justificado pelo fato de que tais sentimentos são associados ao comportamento da mulher, sendo, portanto, sinônimos de franqueza para o homem. Inicialmente, “[...] ele se viu falando com ela na própria angústia, e logo com uma moça! ele que de coração de mulher só recebera o beijo da mãe” (LISPECTOR, 1999, p. 33). Por conta disso: "Naturalmente, o fato dela também sofrer simplificara o modo de se tratar uma moça, conferindo-lhe um caráter masculino. Ele passou a tratá-la como camarada” (LISPECTOR, 1999, p. 34).

Numa aproximação ao mito de Narciso, personagem mitológico que se viu atraído por sua própria imagem refletida na água, o rapaz do conto é fascinado justamente pelo que de comum existe entre ele e a personagem feminina, a angústia, considerada pelo protagonista como uma emoção masculina. Assim como Narciso, que dispensou todas as jovens apaixonadas por sua beleza, podemos dizer que o personagem lispectoriano faz o mesmo, pois não é pelos traços femininos que este inicia uma amizade com a moça, mas por uma característica dele mesmo, refletida na jovem, mas que não poderá alcançar pelo fato de ser ela uma garota.

Nesse ínterim, questões acerca da construção da identidade masculina vão sendo delineadas a partir do convívio entre os dois adolescentes. Do mesmo modo, a identidade feminina vai se revelando inferior na medida em que é construída, permitindo reflexões sobre os papéis sociais e sexuais do sujeito prescritos e impostos aos gêneros como práticas a serem desempenhadas cotidianamente. Marcada pela diferença, a relação entre os jovens é, porém, iniciada justamente por um ponto convergente, o fato de sentirem-se angustiados, e é a partir dele que a narrativa segue seu curso, já com indícios de uma futura separação.

Clarice Lispector tece, por meio da sutileza de sua escrita, uma história voltada para as descobertas típicas da adolescência, quando os jovens se percebem imersos em um sistema composto por dispositivos que exercem sobre eles algum tipo de poder. Sob efeito dessas forças, concentradas principalmente no objetivo de regular suas ações, homens e mulheres são 
educados sobre o que devem ou não fazer, mas é nessa fase antecedente à vida adulta em que há o entendimento seguido, muitas vezes, de um desconforto por saber que: "Quando nascemos, já encontramos a sociedade na qual estamos inseridos com as classificações do que seja pertencente ao gênero masculino e ao gênero feminino" (BENTO, 2015, p. 53).

Cientes dessa verdade, ele mais do que ela, ambos mergulham nesse jogo cujas regras ocultavam mais do que faziam transparecer. Nenhum dos dois, por exemplo, ateve-se ao fato de que o rapaz sentir-se angustiado conferia-lhe características aproximativas do universo feminino, pois, considerando o modelo masculino hegemonicamente estereotipado e legitimado pelo sistema patriarcal, sentimentos como este não poderiam se manifestar. Desta feita: “As angústias inefáveis, diluídas numa vivência difícil de ser captada pelo ritmo alucinante de vida, podem ser representadas por uma crise de identidade de gênero, onde a masculinidade e seus preceitos tradicionais emergem como demandas deslocadas” (OLIVEIRA, 2004, p. 138).

Por conta disso, preferiram masculinizar o sujeito feminino, colocando a angústia como comum ao homem. Quanto a isso, não houve resistência da jovem, pois, como propagado socialmente, a dominância é masculina, restando aos demais a submissão. Cabe ressaltarmos que esse tratamento é restrito aos dois, não sendo externado para terceiros. Os outros são, para eles, exemplos a não serem seguidos por considerarem todos iguais, monótonos, incapazes de compreender o significado de ser um jovem diante de tantas cobranças. Apenas eles compreendiam um ao outro.

O desejo de ser diferente dos outros os conduzia a um caminho de busca pela individualidade, à construção de identidades marcadas pela diferença (WOODWARD, 2014). Não sendo iguais aos outros, eles seriam únicos e todas as suas ações eram pensadas nessa direção. Nas primeiras linhas do texto, o personagem masculino é apresentado como alguém próximo ao universo emocional, pois o narrador o descreve ressaltando sentimentos diversos, muitos deles não considerados adequados para um rapaz. De repente:

Viu-se conversando com ela, escondendo com secura o maravilhamento de enfim poder falar sobre coisas que realmente importavam; e logo com uma moça! Conversavam também sobre livros, mal podiam esconder a urgência que tinham de pôr em dia tudo em que nunca antes haviam falado. Mesmo assim, jamais certas palavras eram pronunciadas entre ambos. Dessa vez não porque a expressão fosse mais uma armadilha de que os outros dispõem para enganar as moças. Mas por vergonha. Porque nem tudo ele teria coragem de dizer, mesmo que ela, por sentir angústia, fosse pessoa de confiança. Nem em missão ele falaria jamais, embora essa expressão tão perfeita, que ele por assim dizer criara, lhe ardesse na boca, ansiosa por ser dita. (LISPECTOR, 1999, p. 33-34, grifos da autora).

Algumas passagens do excerto confirmam o sentimentalismo do personagem. O jovem tenta esconder qualquer ação ou expressão que denuncie sua surpresa em poder conversar sobre assuntos de seu gosto com a garota. Ademais, ele se sente envergonhado quando pensa em tratar determinados assuntos, desistindo de imediato. Um terceiro sentimento tão essencial para a afirmação da masculinidade é ausente no jovem: ele é desprovido de coragem, em face do sujeito feminino, mesmo ela sendo capaz de entendê-lo. Angústia, surpresa, vergonha e medo, características opostas às necessárias para um sujeito ser considerado homem de verdade. 
Em contrapartida, no avançar da narrativa, o personagem vai se tornando diferente do início do conto, em progressão. Ele já não sente mais angústia, pois esse sentimento se tornou comum, superável, ao ponto de não sentir mais a necessidade de falar sobre ele. Aqui é perceptível uma mudança no personagem sempre primeiro. Aos poucos, sua identidade vai sendo construída pela superação de fraquezas, pela proximidade com a jovem, bem como pelo afastamento. Antes de um maior aprofundamento nessa questão, faz-se necessário salientar que:

A identidade - sejamos claros sobre isso - é um "conceito altamente contestado". Sempre que se ouvir essa palavra, pode-se estar certo de que está havendo uma batalha. O campo de batalha é o lar natural da identidade. Ela só vem à luz no tumulto da batalha, e dorme e silencia no momento em que desaparecem os ruídos da refrega. Assim, não se pode evitar que ela corte dos dois lados. (BAUMAN, 2005, p. 83).

É desse modo que as identidades se constroem na narrativa, pela oscilação de convergências e divergências. Ela admite uma identidade masculina, num primeiro momento, mas em seguida não se sente confortável com o papel que lhe é conferido. Já ele, ao tentar esconder sua sensibilidade da amiga, revela um estado interior associado ao campo do sensível. Ambos procuram ser aceitos, porém essa tentativa mostra-se falha, no instante em que percebem se tratar de uma amizade movida pela aparência. "Eles eram muito infelizes. Procuravam-se cansados, expectantes, forçando uma continuação da compreensão inicial e casual que nunca se repetira - e sem nem ao menos se amarem” (LISPECTOR, 1999, p. 36-37).

Quando ele sofria, achava uma gafe ela falar em angústia. "Eu já superei esta palavra”, ele sempre superava tudo antes dela, só depois é que a moça o alcançava. [...]. E aos poucos ela se cansou de ser aos olhos dele a única mulher angustiada. [...]. Sobretudo a moça já começara a não sentir prazer em ser condecorada com o título de homem ao menor sinal que apresentava de... de ser uma pessoa. Ao mesmo tempo que isso a lisonjeava, ofendia um pouco: era como se ele se surpreendesse de ela ser capaz, exatamente por não julgá-la capaz. Embora, se ambos não tomassem cuidado, o fato dela ser mulher poderia de súbito vir à tona. Eles tomavam cuidado. (LISPECTOR, 1999, p. 34-35, grifos da autora).

O conto é permeado por uma atmosfera conflitiva, tensionada pela imposição de uma identidade masculina a um ser do sexo feminino, aceita por ela sem questionamentos iniciais. Ao mesmo tempo, o jovem sente-se pressionado pela conduta reservada a ele, marcada por um monitoramento de seu comportamento, forçando-o a moldar suas atitudes segundo as normas patriarcais. Percebemos, portanto e mais uma vez, a construção de uma identidade influenciada pela diferença. Contudo, essa diferença está intimamente ligada aos aspectos semelhantes entre eles, que são muitos e dão margem para pensarmos na concepção de sujeitos andróginos.

Ao discursar em O banquete, de Platão (1983), Aristófanes remete ao ser andrógino, afirmando ser este a representação do todo humano, constituindo-se, originalmente, como um terceiro gênero, além dos dois já conhecidos. “Com efeito, nossa natureza outrora não era a mesma que a de agora, mas diferente. Em primeiro lugar, três eram os gêneros da humanidade, não dois como agora, o masculino e o feminino, mas também havia a mais um terceiro, comum 
a estes dois” (PLATÃO, 1983, p. 22). Separado por Zeus, o uno tornou-se duplo, dando origem a uma nova forma de amar, já que o tema em discussão era a existência de Eros.

Já Elisabeth Badinter (1993, p. 166) chama atenção para o fato de que “[...] o andrógino sempre teve má reputação. Sua origem mitológica o associa ao monstro hermafrodita”. Grande parte dos estudos referentes à androginia foram baseados nesse princípio e, até mesmo hoje, esse ser é incompreendido. Por outro lado, a partir dele, é possível repensar os papéis sociais de gênero tão restritivos aos homens e às mulheres e confrontar a realidade de épocas antigas com a pós-modernidade. A androginia abre espaço para percebermos as mudanças ocorridas no mundo e a necessidade da expansão das possibilidades de atuação dos gêneros. Consoante a essas ideias:

O andrógino vaga pela terra. Os homens sentem que sua sombra os invade e cedem, deixam de prender-se às suas convicções e papéis masculinos, tão duros e restritivos; as mulheres despertam para novos espaços, definidos com clareza e frieza, para planos coordenados com precisão, nas quais começam a abrir caminho com tranquilidade. (ZOLLA, 1997, p. 5).

Faz-se necessário considerarmos as divisões binárias de gênero, pois o andrógino não elimina seu lado feminino para exaltar o masculino, nem incorpora unicamente sua feminilidade em detrimento da masculinidade. Há uma dualidade necessária que se constitui como fundamental para a manifestação do androginato “que só pode ser duplo” (BADINTER, 1993, p. 166). Nesse sentido, podemos pensar os personagens da narrativa de Clarice Lispector como andróginos, no sentido de que eles, algumas vezes e sem perceber, apresentam características de seu sexo oposto ao mesmo tempo que as do seu próprio. Aos poucos, os dois personagens vão se tornando parecidos, aproximando-se um do outro de forma a adquirirem comportamentos geralmente não permitidos ao seu gênero, como no trecho:

Ela mesma também passou a ostentar com modéstia aureolada a própria angústia, como um novo sexo. Híbridos - ainda sem terem escolhido um modo pessoal de andar, e sem terem ainda uma caligrafia definitiva, cada dia a copiarem os pontos de aula com letra diferente - híbridos eles se procuravam, mal disfarçando a gravidade. Uma vez ou outra, ele ainda sentia aquela incrédula aceitação da coincidência: ele, tão original, ter encontrado alguém que falava a sua língua! Aos poucos compactuaram. Bastava ela dizer, como numa senha, "passei ontem uma tarde ruim”, e ele sabia com austeridade que ela sofria como ele sofria. Havia tristeza, orgulho e audácia entre ambos. (LISPECTOR,1999, p. 34).

Outras passagens também ilustram esse pensamento que vê os personagens como andróginos. A título de exemplo: "Como se fossem homossexuais de sexo oposto, e impossibilitados de unir, em uma só, a desgraça de cada um” (LISPECTOR, 1999, p. 35), ressaltando essa relação de proximidade e de afastamento, da diferença existente entre os dois; ou ainda quando as características de um são percebidas no outro num hibridismo que causa estranhamento devido às classificações de gênero limitadamente instituídas. Vejamos um trecho:

Estava porém suave e indeciso, como se qualquer dor só o tornasse ainda mais moço, ao contrário dela, que estava agressiva. Informes como eram, tudo lhes era 
possível, inclusive às vezes permutavam as qualidades: ela se tornava como um homem, e ele com uma doçura quase ignóbil de mulher. (LISPECTOR, 1999, p. 39).

O narrador faz bom uso das palavras para pontuar aspectos importantes para a compreensão desse texto, ao referir-se a determinadas características masculinas e femininas. A agressividade e a doçura, que podem ser vistas como positivas ou negativas, dependendo do ponto de vista, são tratadas por ele (ou ela) como qualidades. De fato, elas são qualidades se presentes no gênero “adequado”, pois ser agressivo é necessário ao homem como requisito para sua masculinidade assim como a doçura é necessária à mulher, como requisito para sua feminilidade. Qualquer conduta que fuja a essas prescrições é considerada inadequada, comprometendo a honra do indivíduo.

Entretanto, tais qualidades podem ser consideradas negativas, associadas a defeitos, dependendo do grau de ocorrência. Se um homem demonstrar ser agressivo demais em situações desnecessárias, elevando essa postura ao nível da violência, e a mulher uma sensibilidade exagerada, pode ser prejudicial tanto para si mesmo quanto para os outros. É preciso que o homem seja doce em momentos específicos e a mulher mais firme em determinadas situações, pois as relações são diversas e exigem comportamentos distintos. Trata-se, portanto, de uma questão de medida. Em se tratando de literatura:

O novo herói continua sem se identificar com os papéis que lhe são atribuídos e sempre está disposto a experimentar níveis pouco comuns do ser. Pode suprimir os parâmetros binários e conceituais e, por consequência, experimentar situações não dualistas de simetria máxima, como as que predominam na ficção "pósmodernista”. (ZOLLA, 1997, p. 6).

O herói épico era dotado de características que evidenciam seus atributos masculinos. Força, coragem, inteligência e virilidade eram qualidades essenciais e presentes nos personagens das grandes epopeias e seus papéis sociais eram bem definidos, desempenhados pensando num bem coletivo (LUKÁCS, 2000). Com o surgimento da prosa, mais precisamente do romance, o herói voltou-se para sua individualidade e sua subjetividade ganhou destaque na pena dos escritores (WATT, 2010). Com isso, novos tipos masculinos foram surgindo como representações da sociedade e como crítica ao modelo hegemonicamente instituído. Mudanças ocorreram nas maneiras de ser, tendo como reflexo sujeitos dispostos a questionar, mesmo que inconscientemente, as diferenças entre os gêneros.

Pelo aspecto andrógino com que se configura a construção identitária dos personagens lispectorianos, a narrativa permite-nos associá-los aos primeiros seres humanos a habitarem o planeta Terra. Nesse sentido, a narrativa vai apresentando semelhanças ao momento da criação do homem e da mulher descrito na Bíblia. Essa analogia é possível se considerarmos outras versões desse mito, além da conhecida universalmente pelo texto sagrado. "Conta-se que Adão e Eva eram ligados pelas costas e então Deus os separou com uma machadada. Em algumas versões, Adão (o primeiro homem) era metade homem, metade mulher, porém Deus o rachou ao meio e fez dele homem e mulher" (NOLASCO, 2001, p. 26).

As primeiras criações divinas tiveram para si um ambiente repleto de riquezas naturais para o qual receberam a missão de proteger e cultivar. A única proibição era não comer da árvore do conhecimento do bem e do mal, pois, como consequência, estariam condenados à morte. 
A desobediência dos dois, cuja culpa é atribuída a Eva, constituiu-se como o primeiro pecado ou pecado original e, a partir dele, adquiriram consciência de seu estado e um constrangimento pelo fato de estarem despidos. O castigo foi a conhecida divisão dos gêneros com notável vantagem da supremacia masculina sobre a mulher, condenada a satisfazer as vontades de seu companheiro, sendo-lhe submissa.

Vejamos as convergências entre o mito bíblico e o texto de Clarice Lispector: os personagens lispetorianos são jovens, um rapaz e uma moça; num primeiro momento, o menino sente-se angustiado por ser solitário em relação a essa emoção, sanado com a descoberta de outra pessoa igualmente angustiada, uma menina. Ele tenta, a todo instante, não a ver como sendo do sexo feminino, e ela aceita ser tratada como um menino. No entanto, existe um medo de que essa verdade venha à tona e uma drástica mudança aconteça. Nessa perspectiva, a mulher é o ser que causa a perturbação, uma espécie de desequilíbrio, uma quebra de padrões, uma tentação que pode levar o homem a fraquejar diante de seu papel socialmente instituído.

Alguns trechos podem servir como exemplos para fundamentar esse ponto de vista: "Eles apenas concordavam no único ponto que os unia: o erro que havia no mundo e a tácita certeza de que se eles não o salvassem seriam traidores" (LISPECTOR, 1999, p. 35) - que erro seria esse? O pecado de Adão e Eva, ao desobedecerem a ordem divina e comerem o fruto proibido da árvore do conhecimento? -; "O que é, afinal, que queriam? Queriam aprender. Aprender o quê? eram uns desastrados” (LISPECTOR, 1999, p. 36). Na sequência, outro trecho corrobora para essa possibilidade: "[...] se na verdade tocavam, sem nenhum motivo, num tal ponto extremo de felicidade como se o mundo fosse sacudido e dessa árvore imensa caíssem mil frutos” (LISPECTOR, 1999, p. 36).

Nesse estágio da análise, podemos conceber essa analogia em termos de interpretação figural $^{1}$, como sugere Erich Auerbach em seu ensaio "Figura". Segundo o autor de Mimesis, esse tipo de interpretação “[...] estabelece uma conexão entre dois acontecimentos ou duas pessoas, em que o primeiro significa não apenas a si mesmo, mas também ao segundo, enquanto o segundo abrange ou preenche o primeiro" (AUERBACH, 1997, p. 46). Nesse sentido, seriam Adão e Eva figuras ou prefigurações dos personagens lispectorianos? Estariam os dois jovens destinados a concertar o erro cometido por seus originais?

Quanto ao primeiro questionamento, podemos dizer que sim, pois a desobediência de Adão e Eva demarcou as linhas de diferença entre homens e mulheres, desde sua gênese, permanecendo-se firme até a pós-modernidade. É fato que movimentos de engajamento sociais, como o feminismo, por exemplo, conseguiram estreitar esses limites, porém muitos ainda resistem em aderir a mudanças e insistem em defender comportamentos influenciados pelo conservadorismo e pelo tradicionalismo, no que tange às relações de gênero. Já em relação ao segundo, esse destino não se concretiza, pois, como veremos mais adiante, os personagens falham em sua tentativa de "salvar o mundo".

\footnotetext{
1 "Esse tipo de interpretação tinha como objetivo mostrar que todas as pessoas e acontecimentos do Velho Testamento eram prefigurações do Novo Testamento e de sua história de redenção” (AUERBACH, 1997, p. 28).

${ }^{2}$ Auerbach (1997) faz um apanhado sobre as várias significações do termo "figura” na antiguidade, desde a concepção de Terêncio até a de Quintiliano. Ele parte de seu sentido inicial de forma plástica até a utilização como figura de linguagem. Além disso, discorre sobre o sentido deste termo para o mundo cristão, a partir de Tertuliano, que o via como "[...] algo real e histórico que anuncia alguma outra coisa que também é real e histórica” (AUERBACH, 1997, p. 27), e São Paulo.
} 
A nudez foi revelada, o pudor percebido e os desejos do corpo manifestados. Mesmo assim, os personagens não demonstravam interesse um pelo outro, e seus encontros resumiam-se a tratar de assuntos cotidianos, sempre com o cuidado para que a face feminina da garota não viesse à luz. Por haver essa barreira, que de certo modo os impedia de se entregarem verdadeiramente, suas identidades de homem e mulher pouco eram expressas, mas, algumas vezes, seus lados masculinos e femininos davam indícios de suas existências.

Quanto ao amor, eles não se amavam, era claro. Ela até já lhe falara de uma paixão que tivera recentemente por um professor. Ele chegara a lhe dizer - já que ela era como um homem para ele -, chegara mesmo a lhe dizer, com muita frieza que inesperadamente se quebrara em horrível bater de coração, que um rapaz é obrigado a resolver "certos problemas", se quiser ter a cabeça livre para pensar. Ele tinha dezesseis anos, e ela, dezessete. Que ele, com severidade, resolvia de vez em quando certos problemas, nem seu pai sabia. (LISPECTOR, 1999, p. 35-36).

Sem perceber, eles foram amadurecendo e sua preparação para a separação sendo finalizada. "Talvez estivessem tão prontos para se soltarem um do outro como uma gota de água quase a cair, e apenas esperassem algo que simbolizasse a plenitude da angústia para poderem se separar” (LISPECTOR, 1999, p. 38-39, grifo da autora). Desde o início da narrativa isso era previsto, pois a aproximação dos dois sempre esteve fragilizada. Para entender de fato seus sentimentos e acordarem finalmente prontos para a despedida, foi preciso que a emoção compartilhada se materializasse na forma de uma grande e velha casa, trazendo consigo o momento epifânico e a revelação da mensagem. Era uma casa misteriosa que tinha uma penumbra e um prenúncio de algo que há muito tempo existia.

Fixando aquela coisa erguida tão antes deles nascerem, aquela coisa secular e já esvaziada de sentido, aquela coisa vinda do passado. Mas e o futuro?! Oh Deus, dai-nos o nosso futuro! A casa sem olhos com a potência de um cego. E se tinha olhos, eram redondos olhos vazios de estátua. Oh Deus, não nos deixei ser filhos desse passado vazio, entregai-nos ao futuro. Eles queriam ter filhos. Mas não dessa endurecida carcaça fatal, eles não compreendiam o passado: oh livrai-nos do passado, deixai-nos cumprir o nosso duro dever. (LISPECTOR, 1999, p. 42).

O rapaz é sempre o primeiro a dar-se conta dos acontecimentos. Ao perceber que está demonstrando sentimentos considerados femininos automaticamente, reprime-os: "meio que chorar nessa hora é bem de mulher” (LISPECTOR, 1999, p. 43). A esse respeito, Nolasco (2001) realça: “As práticas sociais que definem o universo simbólico masculino são caracterizadas por uma rigidez que comprime os homens a viverem sob condições de limitação emocional” (NOLASCO, 2001, p. 146-147). Só então, ao verem-se diante de uma enorme casa, velha e angustiada, a mensagem contida nessa antiga construção passa a ser conhecida. “A casa simbolizava alguma coisa que eles jamais poderiam alcançar, mesmo com toda uma vida de procura de expressão” (LISPECTOR, 1999, p. 42). Bachelard (2008), também psicanalista, adverte-nos:

Para um estudo fenomenológico dos valores de intimidade do espaço interior, a casa é, evidentemente, um ser privilegiado; isso é claro, desde que a consideremos ao mesmo tempo em sua unidade e em sua complexidade, tentando integrar 
todos os seus valores particulares num valor fundamental. A casa nos fornecerá simultaneamente imagens dispersas e um corpo de imagens. Em ambos os casos, provaremos que a imaginação aumenta os valores da realidade. (BACHELARD, 2008, p. 23).

Assim, a mensagem contida na velha casa ganha voz a partir do comportamento dos dois personagens. Eles eram iguais enquanto seres humanos, porém diferentes aos olhos da sociedade, e a casa vem lhes dizer que o futuro previsto para os dois não é o mesmo. Ele, enquanto homem, terá total liberdade para transitar em espaços exteriores ao lar, de intervir na vida pública onde poderá dominar o comércio, as ruas, os bares, sair sem ter hora para voltar, até ter outras mulheres fora do casamento, já que ele é homem, e essa condição lhe dá plena liberdade para isso.

Já ela viverá dentro da casa, no ambiente interior. Terá de limpá-la, cozinhar, lavar, passar, cuidar do marido e dos filhos que obrigatoriamente deverá ter. Uma espécie de prisão domiciliar, sem grades, sem algemas, com barreiras simbólicas impostas por uma sociedade predominantemente machista que duvida do seu potencial enquanto mulher. Uma sociedade patriarcal que prega a superioridade do masculino sobre o feminino, impondo a estas um pedido de permissão para qualquer atividade que deseje executar. Como afirma Pierre Bourdieu:

A força da ordem masculina se evidencia no fato de que ela dispensa justificação: a visão androcêntrica impõe-se como neutra e não tem necessidade de se enunciar em discursos que visem a legitimá-la. A ordem social funciona como uma imensa máquina simbólica que tende a ratificar a dominação masculina sobre a qual se alicerça: é a divisão sexual do trabalho, distribuição bastante estrita das atividades atribuídas a cada um dos dois sexos, de seu local, seu momento, seus instrumentos; é a estrutura do espaço, opondo o lugar de assembleia ou de mercado, reservados aos homens, e a casa, reservada às mulheres; ou, no próprio lar, entre a parte masculina, com o salão, e a parte feminina, com o estábulo, a água e os vegetais; é a estrutura do tempo, as atividades do dia, o ano agrário, ou o ciclo de vida, com momentos de ruptura, masculinos, e longos períodos de gestação, femininos. (BOURDIEU, 2016, p. 22, 24).

Ao perceberem a realidade secular que os afasta e diferencia, através do momento epifânico tão marcante na obra de Clarice Lispector, os dois jovens separam-se indo cada um para um lado. Ele, ciente dos privilégios a que tem direito, permanece firme em seu corpo de macho; ela, abatida, como se já pressentisse a vida injusta de mulher que a espera, segue seu caminho agora no seu corpo de fêmea. Apressada para não perder o ônibus, ela sai sem olhar para trás; ele a observa até que ela sente no banco do transporte. No final do conto, com sua identidade parcialmente edificada e ironicamente sozinho, o personagem masculino chama por outra mulher, com quem manteve, quando infante, intenso contato, mas por conta das condições para o afloramento de sua virilidade, segundo manda os ritos de masculinização dos meninos ${ }^{3}$, não deveria recorrer: aquela que o carregou provavelmente nove meses dentro de seu útero; aquela a quem ele chama de mãe.

\footnotetext{
${ }^{3}$ Em muitas sociedades é necessário afastar os filhos homens das mães para que não sejam contaminados com a feminilidade. Para tanto, ritos de iniciação ao mundo dos homens devem ser experienciados. "O objetivo comum desses ritos é mudar o estatuto de identidade do menino para que ele renasça homem” (BADINTER, 1993, p. 71).
} 
Já sabemos da angústia sentida no início do conto. Sabemos também da surpresa de encontrar compreensão justamente em alguém a quem não pensava ser capaz de se sentir angustiada; vimos a superação desse sentimento concomitantemente à construção de sua identidade de adolescente e homem; presenciamos ainda o androginato dos personagens pelas manifestações dualísticas de suas características, permitindo enxergar em Adão e Eva suas respectivas "figuras”. Resta-nos atentarmos para os efeitos do grande acontecimento da casa para o entendimento da enigmática mensagem escondida nos destroços “[...] daquela coisa erguida tão antes deles nascerem, aquela coisa secular e já esvaziada de sentido, aquela coisa vinda do passado” (LISPECTOR, 1999, p. 42) prestes a devorá-los.

Enfim ambos haviam inesperadamente alcançado a meta e estavam diante da esfinge. Boquiabertos, na extrema união do medo e do respeito e da palidez, diante daquela verdade. A nua angústia dera um pulo e colocara-se diante deles - nem ao menos familiar como a palavra que eles tinham se habituado a usar. Apenas uma casa grossa, tosca, sem pescoço, só aquela potência antiga. (LISPECTOR, 1999, p. 41).

Materializada na forma de uma casa, a angústia dos personagens ansiava por um futuro, possível apenas se eles fossem capazes de decifrar o enigma da esfinge ${ }^{4}$, ela própria insistente em negar a existência de um em seus espaços poéticos e carregados de sentido. "Eu sou enfim a própria coisa que vocês procuravam, disse a casa grande. E o mais engraçado é que não tenho segredo nenhum, disse também a grande casa” (LISPECTOR, 1999, p. 41). Mesmo assim, havia a necessidade da revelação, pois os dois personagens precisavam acordar de seus devaneios e se deparar com a crueza do mundo e sua realidade. Eles precisavam compreender a mensagem, decodificar a charada esfíngica.

Gaston Bachelard realizou um importante estudo sobre as significações dos espaços da casa para além de suas meras divisões em cômodos. Nesse ambiente, é possível empreender jornadas subconscientes rumo à produção de subjetividades envolvendo todo um imaginário do passado, do presente e do futuro. Nele, é possível ter a sensação de proteção, de privacidade, de estar livre para ser o que se é, de descanso, enfim, de ter uma vida. Dinâmicas contrárias também são viáveis. Além disso, a casa diz muito sobre o desempenho social dos sujeitos, pois a dicotomia interior/exterior ganha todo sentido nas paredes divisórias erguidas para a distinção: "No equilíbrio íntimo das paredes e dos móveis, pode-se dizer que tomamos consciência de uma casa construída pelas mulheres. Os homens só sabem construir as casas do exterior. Não conhecem a civilização da cera” (BACHELARD, 2000, p. 80-81).

No texto lispectoriano, a casa aparece como símbolo de divisão entre os gêneros masculino e feminino, necessária para a identificação de suas condições e posições a serem ocupadas no âmbito social. Nesse sentido, ela vem revelar-lhes a mensagem existente no contexto da época em que foi escrito o conto, como sabemos, a década de 1960, quando o homem dominava o mundo exterior ao da casa, bem como o interior, com liberdade para transitar nesses dois planos. Em contraponto, a mulher vivia ainda dentro da casa, com pouco acesso para adiante das

\footnotetext{
${ }^{4}$ Esta criatura mitológica aparece ligada à ideia de enigma e o seu era proposto a todos que lhe cruzassem o caminho, tendo como consequência, caso errassem, a morte. "Qual é o animal que de manhã anda com quatro pés, à tarde com dois e à noite com três?” (BULFINCH, 2017, p. 128). O único capaz de decifrá-lo foi Édipo com a resposta: "É o homem, que engatinha na infância, anda ereto na juventude e com a ajuda de um bastão na velhice” (BULFINCH, 2017, p. 128).
} 
portas e janelas, reclusa, mas com a chama do feminismo sentindo o cheiro da pólvora cujo fogo libertário começava a faiscar. Após o contato inesperado com a misteriosa construção:

Ainda vacilante, ele esperou com polidez que ela se recompusesse. Esperou vacilante, sim, mas homem. Magro e irremediavelmente moço, sim, mas homem. Um corpo de homem era a solidez que o recuperava sempre. Volta e meia, quando precisava muito, ele se tornava um homem. Então, com mão incerta, acendeu sem naturalidade um cigarro, como se ele fosse os outros, socorrendo-se dos gestos que a maçonaria dos homens lhe dava como apoio e caminho. E ela?

Mas a moça saiu de tudo isso pintada com batom, com o ruge meio manchado, e enfeitada por um colar azul. Plumas que um momento antes haviam feito parte de uma situação e de um futuro, mas agora era como se ela não tivesse lavado o rosto antes de dormir e acordasse com as marcas impudicas de uma orgia anterior. Pois ela, volta e meia, era uma mulher. (LISPECTOR, 1999, p. 44, grifo da autora).

Eles se tornaram agora homem e mulher sem máscaras ou identidades impostas, cada um com suas próprias características e cientes de suas diferenças. Foi justamente pela descoberta da diferença que os personagens se viram com seus traços masculinos e femininos, despidos. O andrógino foi dividido, o fruto proibido foi mais uma vez degustado e o conhecimento trouxe consigo a separação acompanhada do fracasso em salvar o mundo. Em termos de "figura”, o primeiro acontecimento (o de Adão e Eva) significou o segundo, e o segundo (o dos personagens lispectorianos) realizou o primeiro, conforme aponta Auerbach (1997, p. 9). "Ele tinha acabado de nascer homem” (LISPECTOR, 1999, p. 46) e como homem inserido em um contexto regido por ditames patriarcais, tem uma identidade social masculina deslocada (HALL, 2015) a experienciar.

O desfecho traz consigo a ironia diante do percurso feito pelo personagem até descobrir-se diferente da mulher. Ela se apressou sem necessidade para pegar o ônibus e ir embora. Já ele, mesmo surpreso pela forma como a menina subiu no transporte, devaneou um pouco mais até recobrar a consciência do que fora "[...] apenas um instante de fraqueza e vacilação" (LISPECTOR, 1999, p. 46). Sozinho e com os farelos da mensagem dispersados na poeira "[...] à mercê da mentira pressurosa com que os outros tentavam ensiná-lo a ser um homem" (LISPECTOR, 1999, p. 47, grifo da autora), acaba por chamar, em retorno ao que a sociedade insistia em afastá-lo (NOLASCO, 2001, p. 106), por sua mãe: “Mamãe, disse ele” (LISPECTOR, 1999, p. 47).

\section{ÚLTIMAS PALAVRAS}

Como? É o homem apenas um erro de Deus? Ou é Deus unicamente um erro do homem? Quem "criou” quem? Ou seria como se criou?.

(Friedrich Nietzsche)

Sob o título provocativo É preciso mais que barro para construir um homem: a identidade do personagem masculino no conto “A mensagem”, de Clarice Lispector, procuramos problematizar as questões que envolvem a identidade do jovem personagem diante da ascensão de sua masculinidade. No percurso, evocamos elementos da religiosidade cristã e da mítica 
grega, além de recorrermos aos estudiosos da masculinidade para refletirmos sobre o processo de construção identitária do sujeito masculino. Além disso, nos detemos na fase jovem da vida do homem, etapa esta em que muitos questionamentos o rodeiam, muitos deles provocados pela figura feminina. Feito isso, destacamos a seguir algumas considerações.

O adolescente protagonista do conto “A mensagem” inicia seu processo de formação ao se deparar com uma personagem feminina na qual se vê refletido, numa associação ao mito de Narciso. Sua identidade é construída pela diferença entre ele e a menina, porém, num primeiro momento, é justamente pela semelhança que os dois se aproximam. Seduzido por sua própria imagem, como se estivesse diante da fonte, ele se interessa pela companhia dela, mas nunca poderá alcançá-la, por estar diante de uma mulher. Ela, podemos dizer, na condição de ser masculino a qual é consagrada, vê-se incapaz de rebater a tal qualificação, respondendo, assim como Eco, apenas à voz masculina.

Dessa relação narcísica, parte-se para o caráter figural desses personagens, como significações de Adão e Eva e seu pecado cometido no texto bíblico. Como seres andróginos em que um apresenta, além das suas, caraterísticas do outro gênero, eles são repartidos ao meio quando se deparam com a personificação de suas angústias na forma de uma casa antiga, portadora da mensagem. Diante dela, a separação final e o retorno ao útero, ou seja, a sua mãe, consagrando, assim, a sensibilidade do rapaz. Por fim, este termina a narrativa com sua identidade masculina ainda em construção, tendo como única certeza sua superioridade em relação ao sujeito feminino, como mandam as instruções dos “outros” a quem tanto ignorava.

\section{REFERÊNCIAS}

AUERBACH, E. Figura. São Paulo: Editora Ática, 1997.

BACHELARD, G. A poética do espaço. São Paulo: Martins Fontes, 2000.

BACHELARD, G. A poética do espaço. 2. ed. São Paulo: Martins Fontes, 2008.

BADINTER, E. XY: sobre a identidade masculina. Rio de Janeiro: Nova Fronteira, 1993.

BAUMAN, Z. Identidade: entrevista a Benedetto Vecchi. Rio de Janeiro: Zahar, 2005.

BENTO, B. O homem não tece a dor: queixas e perplexidades masculinas. Natal: EDUFRN, 2015.

BOURDIEU, P. A dominação masculina. Rio de Janeiro: BestBolso, 2016.

BULFINCH, T. O livro de ouro da mitologia grega: histórias de deuses e heróis. Rio de Janeiro: HarperCollins Brasil, 2017.

HALL, S. A identidade cultural na pós-modernidade. 12. ed. Rio de Janeiro: Lamparina, 2015. LISPECTOR, C. A legião estrangeira. Rio de Janeiro: Rocco, 1999.

LUCKÁCS, G. A teoria do romance. São Paulo: Duas Cidades; Ed. 34, 2000.

MASS, P. W. O cânone mínimo: o bildungsroman na história da literatura. São Paulo: Editora UNESP, 2000. 
NOLASCO, S. De Tarzan a Homer Simpsom: banalização e violência masculina em sociedades contemporâneas ocidentais. Rio de Janeiro: Rocco, 2001.

OLIVEIRA, P. P. A construção social da masculinidade. Belo Horizonte: Editora UFMG; Rio de Janeiro: IUPERJ, 2004.

PLATÃO. O banquete. In: PLATÃO. Diálogos. 2. ed. São Paulo: Abril Cultural, 1983. p. 7-53. WATT, I. A ascensão do romance. São Paulo: Companhia das Letras, 2010.

WOODWARD, K. Identidade e diferença: uma introdução. In: SILVA, T. T. (org.). Identidade e diferença: a perspectiva dos estudos culturais. 15. ed. Petrópolis: Vozes, 2014. p. 7-72.

ZOLLA, E. Androginia. Madrid: Edições Delprado, 1997. 